Original article

\title{
Effect of solvents and extractors on proximate analysis, pharmacognostical screening and chromatographic analysis of Decalepis nervosa (Wight \& Arn.) Venter leaf : An endangered plant from Western Ghats region
}

\author{
M. Saifulla Khan and Kuntal Das * \\ Department of Pharmacognosy and Phytochemistry, Krupanidhi College of Pharmacy, Carmelaram Post, Varthur \\ Hobli, Bangalore-560035, Karnataka, India
}

Received October 20, 2019: Revised December 13, 2019: Accepted December 15, 2019: Published online December 30, 2019

\begin{abstract}
Decalepis nervosa (DN) (Family: Apocynaceae), an endangered demanding medicinal plant of traditional system of medicine. The plant has been focused by many scientists for research and drug discovery sector. Its roots are used by tribal Indian for use as pickles. But still no research related to its medicinal as well as therapeutic values has been done. In the present study, leaf of the plant was evaluated for proximate analysis in terms of moisture content, ash values and extractive values. Histological nature of leaf was detected with powder microscopy and confirmed with scanning electron microscopy (SEM) of the plant for the first time. Further, leaf sample was extracted with $80 \%$ methanol and aqueous solvents by conventional (soxhlet) and modern (microwave) extractors, followed by detail pharmacognostical screening through various chemical tests. Based on strong positive tests, contents of total phenolics and flavonoids were estimated. Thereafter, TLC and HPLC methods were applied for detection and analysis of particular secondary metabolites in both the extracts. Leaf powder microscopy as well as SEM study of leaf revealed the presence of epidermal cells, paracytic stomata, xylems, prismatic calcium oxalate crystals, unicellular covering trichomes, etc. Thereafter, estimated plant constituent resulted in high content of phenolics and flavonoids in microwave extracted methanolic extract $(80 \%)$. TLC and HPTLC study revealed the presence of gallic acid, rutin and quercetin and their content was high in $80 \%$ methanolic extract (microwave method) than soxhlet method. Significant correlation was observed $(p<0.001)$ among methanolic yield with the content of plant constituents. Pharmacognostical study, proximate analysis and extraction parameters of DN leaf identified the presence of phenolic compounds which helps in many therapeutic efficacies as well drug discovery in future.
\end{abstract}

Key words: Decalepis nervosa (Wight \& Arn.) Venter, analysis, proximate analysis, microscopic character, scanning electron microscopy

\section{Introduction}

India is a treasurer of wide range of medicinal and aromatic plants due to presence of varied climatic condition. This climatic diversity helps to grow a vast number of plant species (i.e., nearly 48,000 ) among them, about 17000 plant species are angiosperms (Bapat et al., 2008), but due to the over-exploitation and habitat loss, many plant species are became endangered. The IUCN (International Union for Conservation of Nature and Natural Resources) has listed red labeled plant species of the World, about 34,000 plants among that more than 560 plant species are threatened species from India itself (Phartyal et al., 2002). Plants recognition is very multifaceted and also difficult tusk because plants are extremely complex but

Author for correspondence: Dr. Kuntal Das

Professor, Department of Pharmacognosy and Phytochemistry, \#12/1, Krupanidhi College of Pharmacy, Chikkabelandur, Carmelaram Post, Varthur Hobli, Bangalore-560035, Karnataka, India

E-mail: drkkdsd@gmail.com

Tel.: +91-9632542846

Copyright (c) 2019 Ukaaz Publications. All rights reserved.

Email: ukaaz@yahoo.com; Website: www.ukaazpublications.com several methods are familiar to the plant taxonomist, the way they authenticate plants. Several ways are available to categorize a vast number of different species when there are various plant species which composed of similar parts such as roots, stems, leaves, etc. (Hassoon et al., 2016). Initially, any plant recognition is carried out based on leaves, flowers and fruits morphology. Based on this concept in the present study, Decalepis species is selected. Among all plant species, Decalepis plant is one such species which is become endangered. It has five species such as Decalepis hamiltonii, Decalepis arayalpathra, Decalepis khasiana, Decalepis nervosa and Decalepis salicifolia which are grown in hilly regions only. Except D. khasiana, rest all four species are became endangered (Sharma and Shahzad, 2014). These plant species are very similar to each other so difficult to identify proper plant species. Among the species, Decalepis nervosa (Wight \& Arn.) Venter plant is critically endangered medicinal plant of India, especially in Karnataka, Kerala and Tamil Nadu. The plant is climber, belongs to Apocynaceae family and commonly known as Nerved-leaf Swallow root (Udayan et al., 2013). The plant is located Western Ghats of Nilgiris of Tamil Nadu (Ionta, 2009). Traditionally, many 
medicinal activities pertaining to all Decalepis root species are listed such as treatment of digestive system, lungs and circulatory system except DN species (Sharma and Shahzad, 2014). Some important phytoconstituents are also isolated from roots of $D$. hamiltonii such as inositols, saponins, amyrins, lupeols and also oil (especially vanillin isomer) (Murti and Seshadri, 1941; Nagarajan et al., 2001). Four chemical compounds such as Stelmatocryptonoside A, B, C and $\mathrm{D}$ are isolated from the stems of D. khasiana (Zhang et al., 2002), but no such report on DN plant. Hence, it is worthwhile to explore DN species through biological evaluation (morphology and microscopy), proximate analysis (moisture content, ash values, extractive values, metal ion contents) and study details on DN leaf extract for identification and estimation of plant constituents along with of solvents used in various method of extraction. With this aim, the present study was carried out.

\section{Materials and Methods}

\subsection{Collection of DN leaf sample}

DN leaf sample was collected from Western Ghats region of Tamil Nadu in month May, 2018 and the same was authenticated by Dr. P.E. Rajasekharan, Principal Scientist, Department of Plant Biotechnology, Indian Institute of Horticultural Research, Bangalore. The leaves were preserved in Pharmacognosy laboratory as herbarium (Herbarium numbers: SK-DNL/KCP-109/2018) (Figure 1).

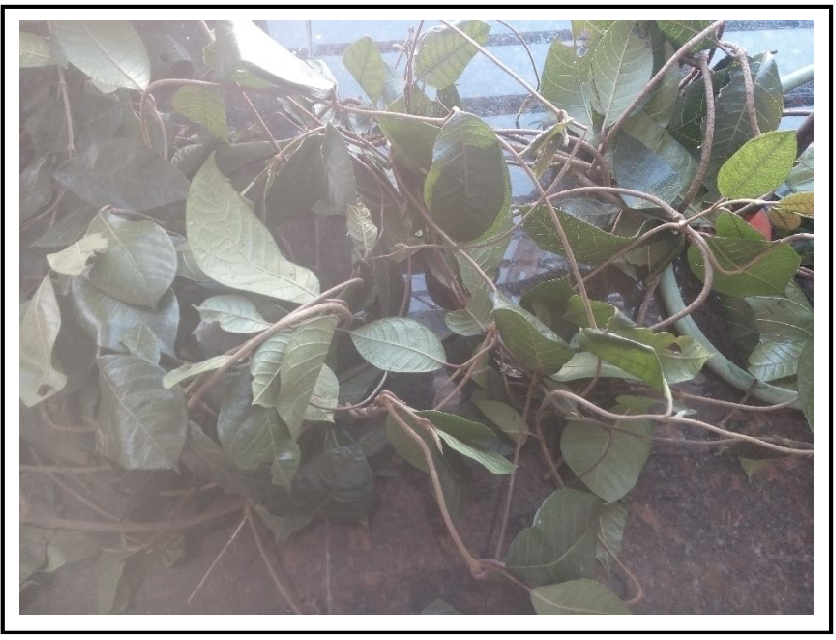

Figure 1: Decalepis nervosa leaves.

\subsection{Proximate analysis of DN leaves}

The powder of DN leaves was subjected to evaluate ash contents (total ash, acid insoluble ash, alcohol soluble ash), water and alcohol soluble extractive values and moisture content.

\subsubsection{Total ash content}

Total ash was determined as per method described by AOAC (AOAC, 1995). $1 \mathrm{~g}$ of dried powdered was kept in a silica crucible in a muffle furnace with temperature of at $450^{\circ} \mathrm{C}$ for $2 \mathrm{~h}$. After ash, it was then cooled in a desiccator and weighed. It was once again heated in the muffle furnace for half an hour, cooled and weighed. The procedure was repeated until to get the constant weight. Total ash content was determined with the following formula:
Percentage of ash $=\frac{\text { Weight of ashed sample }}{\text { Weight of sample taken }} \times 100$

\subsubsection{Alcohol soluble ash}

The ash obtained was digested with $25 \mathrm{ml}$ of alcohol as solvent for $30 \mathrm{~min}$ in a boiling water bath. The content in the silica crucible was filtered by using ash less filter paper (Whatman filter paper No: 42). The filter paper with residue was removed carefully and placed in the same crucible. Then dried in hot air oven and ignited in muffle furnace at $600^{\circ} \mathrm{C}$ for $1 \mathrm{~h}$ and then cooled in a desiccator and weighed. The soluble ash value was determined as per the formula given below (Ajeesh Krishna et al., 2014):

Percentage of alcohol,

$$
\text { soluble ash }=\frac{\text { Weight taken of soluble ash }}{\text { Total weight taken of ash }} \times 100
$$

\subsubsection{Acid insoluble ash}

The ash obtained was boiled with $25 \mathrm{ml}$ of $2 \mathrm{~N} \mathrm{HCl}$ for 5 to $10 \mathrm{~min}$. Then the solution was filtered on an ash less filter paper and the insoluble matter was collected. This insoluble matter was further washed with hot water, ignited and weighed. The percentage of acid insoluble ash was calculated with reference to the air dried drug.

\subsubsection{Moisture content}

The crucible was placed inside the drying oven at $105^{\circ} \mathrm{C}$ for $2 \mathrm{~h}$. Then the crucible was placed in the desiccators and cooled. The beaker was weighed and $5 \mathrm{~g}$ of the powder was placed in the beaker. The sample was dried in oven at $105^{\circ} \mathrm{C}$ for $3 \mathrm{~h}$. Then the dried and cooled sample was weighed and percent of moisture content was determined as per following formula (Ajeesh Krishna et al., 2014):

Percentage of moisture content,

$$
=\frac{\text { Weight of sample }- \text { Weight of dried sample }}{\text { Weight of sample }} \times 100
$$

\subsubsection{Extractive values}

Five $\mathrm{g}$ of leaves were coarsely powdered and was subjected to macerate for $24 \mathrm{~h}$ in a closed iodine flask using $100 \mathrm{ml}$ of two different solvents, viz., alcohol and distilled water. The flask was frequently shaken during the first $3 \mathrm{~h}$ and then allowed to stand for overnight $(24 \mathrm{~h})$. After $24 \mathrm{~h}$, the content in the flask was filtered using Whatman No: 42 filter paper and poured $20 \mathrm{ml}$ in a perti plate and was evaporated to dryness in hot air oven at $105^{\circ} \mathrm{C}$ and weighed after dried. The percentage of soluble extractive was calculated as follows:

$$
\begin{aligned}
& \text { Percentage of extracting value, } \\
& =\frac{\text { Weight of flask with extract }- \text { Weight of empty flask }}{\text { Weight of sample }} \times 100
\end{aligned}
$$

\subsection{Powder microscopy}

Shade dried DN leaves were finely powdered and studied under microscope. Small quantity of powder was placed separately on slides and each slide was mounted 2-3 drops of chloral hydrate, followed by phlouroglucinol and conc. $\mathrm{HCl}$ and each slide was covered with cover slip then examined under microscope. Different cell components were noted and photography was recorded. The same was confirmed with SEM study. 


\subsection{Extraction of DN leaves}

Two different methods were carried out using soxhlet as well as microwave assisted extraction methods using $80 \%$ methanol and aqueous solutions as solvents.

\subsubsection{Extraction by soxhlet method}

Fifteen $g$ of leaves powder was separately extracted with above two solvents. It was performed using soxhlet apparatus for $3 \mathrm{~h}$ using methanol and aqueous solvents. Total volume of the system was kept $100 \mathrm{ml}$. Finally, the yield of extract was calculated after concentrated the crude extract rotary flash evaporator (water bath temperature $45^{\circ} \mathrm{C}$ ). Extracts were kept in refrigeration condition at $4^{\circ} \mathrm{C}$ for further investigation.

\subsubsection{Extraction by microwave method}

$15 \mathrm{~g}$ of dried powder was suspended in $100 \mathrm{ml}$ of aqueous and methanol solution separately in a $250 \mathrm{ml}$ teflon extraction vessel. The vessel was placed in the microwave apparatus and heated at 80 $\mathrm{s}$ at $600 \mathrm{~W}$. The vessel was allowed to cool at $25^{\circ} \mathrm{C}$ then filtered with Whatmann filter paper and dried by evaporation of obtained extract and yield was calculated. Thereafter, extracts were preserved in small glass bottles under refrigeration $\left(4^{\circ} \mathrm{C}\right)$ for further experimentation.

\subsection{Phytochemical screening and TLC identification}

Qualitative phytochemical screening for both the extracts was performed by chemical tests using the standard methods (Harborne, 1973; Trease and Evans, 1989; Sofowara, 1993). Thereafter, based on group of constituent present, TLC and HPTLC were performed for identification, separation and quantification of the constituent present in the DN leaf extracts.

\subsubsection{TLC study}

Various solvent systems were used for identification of main phytoconstituents present in the DN leaf extract.

\subsubsection{HPTLC estimation}

The methanolic extract was reconstituted in methanol at the strength of $5 \mathrm{mg} / \mathrm{ml}$. Further, different concentrations of standards were prepared at the range of 40-400 ng/spot for getting standard calibration curve.

\subsubsection{Chromatographic condition}

Samples are applied on precoated silica gel $60 \mathrm{~F}_{254}$ TLC plates $(20 \times 10 \mathrm{~cm})$ by Linomat V sample applicator. The sample volume is applied in $4.0 \quad 1$ each as $5 \mathrm{~mm}$ band length in $3 \times 10$ silica gel. Reprostar Chromatography Documentation Apparatus (RCDA) is used for photographs of the HPTLC plates.

\subsubsection{Detection and quantification}

The layers of sample and standard were developed to a distance of $80 \mathrm{~mm}$, with toluene: ethyl acetate: formic acid $(7: 5: 1, \mathrm{v} / \mathrm{v})$, as mobile phase, in a chamber, previously saturated with mobile phase vapor at room temperature. After removal of plates from chamber, completely dried in air at room temperature and peak areas for samples and standard were recorded by densitometry in absorbance/ reflectance mode at $\lambda$ max $=254$ and $366 \mathrm{~nm}$, by means of a CAMAG TLC Scanner 3 with win CATS version [3.2.1] (Tiwari et al., 2012).

\section{Stock solution of gallic acid}

Gallic acid $(10 \mathrm{mg})$ was dissolved in methanol and made up to $10 \mathrm{ml}$ volume to yield a concentration of $1 \mathrm{mg} / \mathrm{ml}$.

Stock solution of quercetin

Quercetin $(10 \mathrm{mg})$ was dissolved in methanol and made up to $10 \mathrm{ml}$ volume to yield a concentration of $1 \mathrm{mg} / \mathrm{ml}$.

\subsection{Correlation study}

Correlation between two different modes of extraction with yield of the extracts followed by content of phenolics and flavonoids was established. All data statistically analyzed for the significant study.

\subsection{Statistical analysis}

Data are expressed as mean \pm SD from three replications. For correlation study among the yield, elements contents and total phytochemical presents, one-way ANOVA test followed by Tukey's test $(p<0.05)$ was performed. Thereafter, elemental contents in powdered drug along with various solvent extracted samples were statistically analysed through one way ANOVA test, followed by Dunnett comparative test. $p$ values $<0.05$, considered statistical significant.

\section{Results}

\subsection{Proximate analysis}

\subsubsection{Ash content}

Total ash, alcohol soluble and acid insoluble ash was determined and results were tabulated in Table 1 .

Table 1: Determination of ash content

\begin{tabular}{|l|l|}
\hline Type of ash content & Ash values (\%) \\
\hline Total ash & $7.86 \pm 0.04$ \\
Alcohol soluble ash & $2.72 \pm 1.16$ \\
Acid insoluble ash & $6.41 \pm 0.28$ \\
\hline
\end{tabular}

\subsubsection{Moisture content}

Air dried powdered DN leaf sample was determined for moisture content and result revealed the percentage total moisture content was $6.21 \pm 0.21$.

\subsubsection{Extractive values}

Alcohol and water soluble extractive values were determined as per procedure described in the method and results were depicted in Table 2 .

Table 2: Determination of extractive value

\begin{tabular}{|l|c|}
\hline Type of extractive value & Extractive values (\%) \\
\hline Alcohol soluble & $43.27 \pm 0.41$ \\
Water soluble & $6.27 \pm 1.14$ \\
\hline
\end{tabular}

Mean $\pm \mathrm{SD} ;(\mathrm{n}=3)$

\subsection{Powder microscopy}

Detail powder microscopy of the DN leaf was carried out and resulted presence of epidermal cells, paracytic stomata, unicellular trichomes, xylem fibres, prismatic calcium oxalate crystals, etc., (Figure 2). Further SEM study confirmed the presence of observed cell components in DN powdered leaf (Figure 3). 


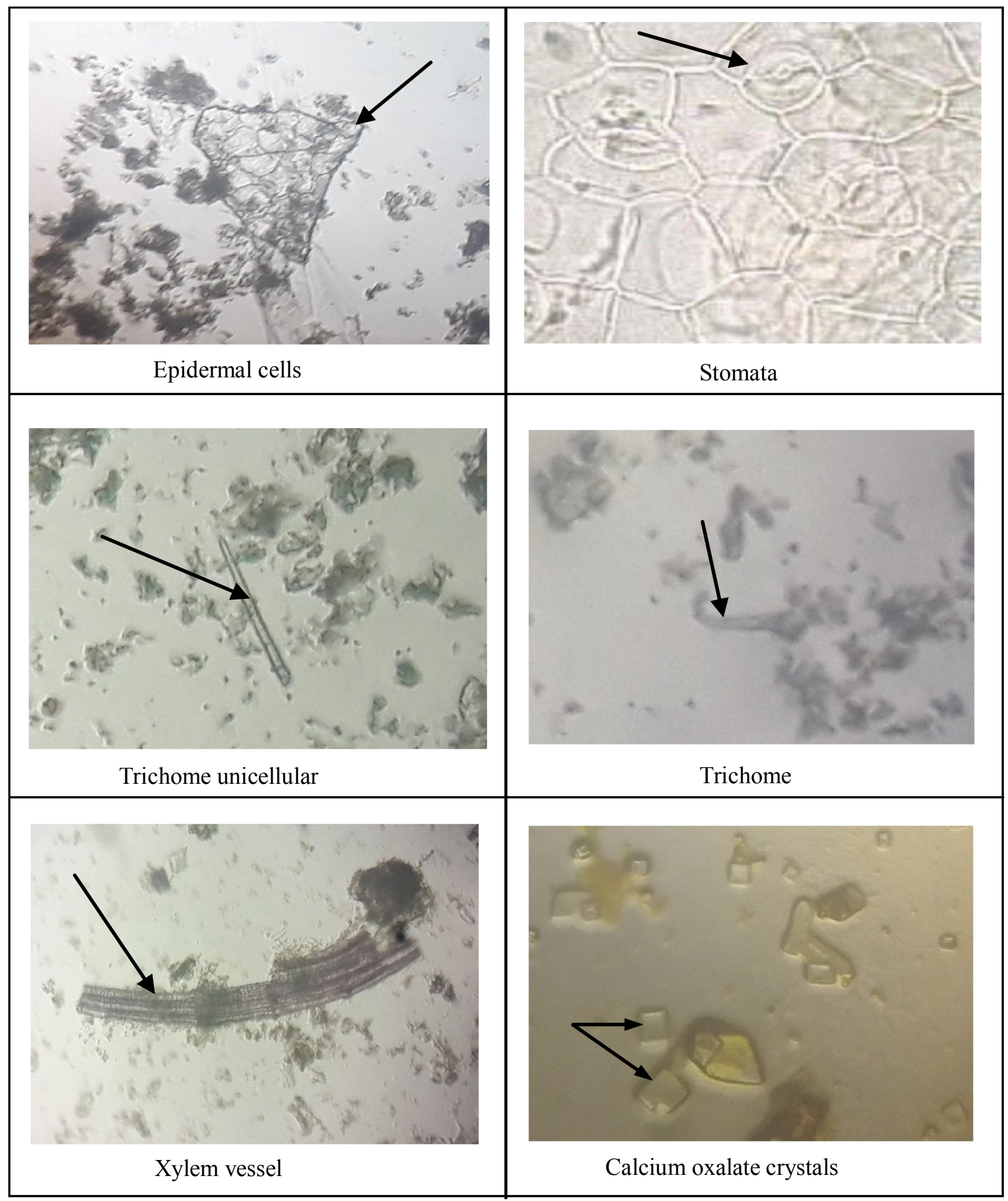

Figure 2: Powder microscopy of DN leaf (magnification at 45x). 


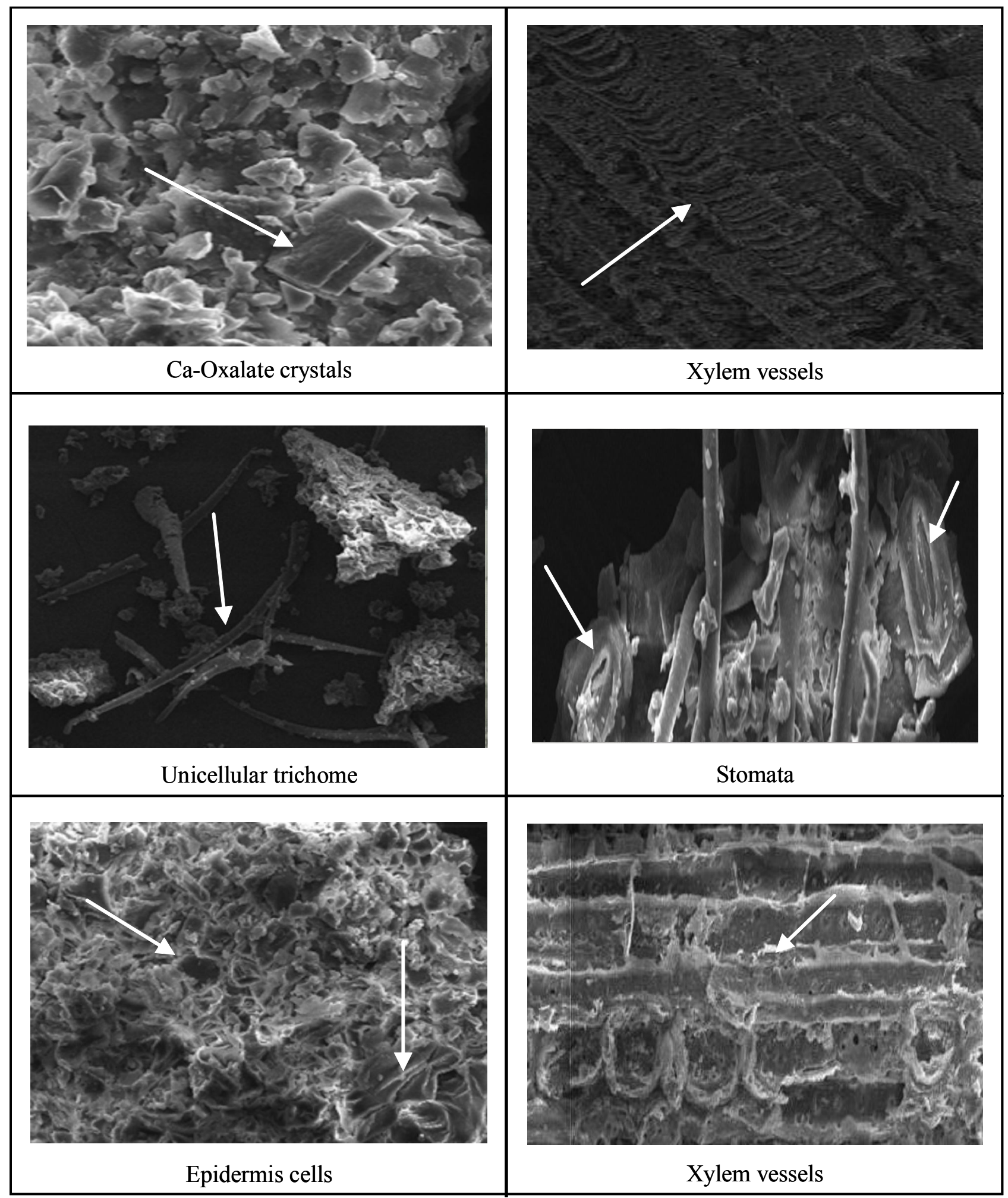

Figure 3: SEM analysis of DN leaf sample. 


\subsection{Extraction}

There were two different methods applied for extractions, viz., soxhlet and microwave and resulted higher percentage of yield with microwave extracted methanol extract (18.24\%), followed by methanolic soxhlet method (12.03\%) (Table 3$)$.

\subsection{Phytochemical Screening}

Various chemical tests were performed as per the above described method for both the extracted sample and revealed the presence of glycoside, phenols, alkaloid and flavonoids. Microwave extracted methanol extract of DN leaf showed better results than aqueous extract (Table 4).

Table 3: Percentage yield of DN leaf extracts

\begin{tabular}{|c|c|c|c|c|c|}
\hline \multirow[t]{2}{*}{ Solvents } & \multirow{2}{*}{$\begin{array}{c}\text { Raw material } \\
\text { used (g) }\end{array}$} & \multicolumn{2}{|c|}{ Extract (w/w) } & \multicolumn{2}{|c|}{ Percentage yield } \\
\hline & & Soxhlet method & Microwavemethod (w/w) & \begin{tabular}{|l|} 
Soxhlet method \\
\end{tabular} & Microwave extraction \\
\hline $80 \%$ methanol & 100 & $12.03 \mathrm{~g}$ & $18.24 \mathrm{~g}$ & $12.03 \%$ & $18.24 \%$ \\
\hline Aqueous & 100 & $10.05 \mathrm{~g}$ & $14.13 \mathrm{~g}$ & $10.05 \%$ & $14.13 \%$ \\
\hline
\end{tabular}

Table 4: Phytoconstituents present in different extracts of DN leaves

\begin{tabular}{|c|c|c|c|c|}
\hline \multirow[t]{2}{*}{ Constituents } & \multicolumn{2}{|c|}{ Soxhlet method } & \multicolumn{2}{|c|}{ Microwave method } \\
\hline & Methanol extract & Aqueous extract & Methanol extract & Aqueous extract \\
\hline Protein & - & - & - & - \\
\hline Lipid & - & - & - & - \\
\hline Carbohydrate & - & + & - & - \\
\hline Alkaloids & + & + & ++ & + \\
\hline Glycoside & + & + & ++ & + \\
\hline Phenolics & + & + & ++ & + \\
\hline Saponins & - & - & - & - \\
\hline Flavonoids & + & + & ++ & + \\
\hline Terpenoids & + & - & ++ & - \\
\hline Steroids & - & - & + & - \\
\hline Tannins & - & - & - & - \\
\hline Resins & - & - & - & - \\
\hline
\end{tabular}

$(+)=$ Weak positive; $(++)=$ Strong positive; $(-)=$ Absent.

Chromatographic analysis of DN extracts

Various solvents were applied and standardized the method with Toluene: Ethyl acetate: Formic acid (7: 5: 1, v/v) for the presence of active constituents. The $R_{f}$ was found 0.64 (Figures $4 a$ and $4 b$ ) for gallic acid and for quercetin is 0.68 for microwave extracted DN leaf sample.

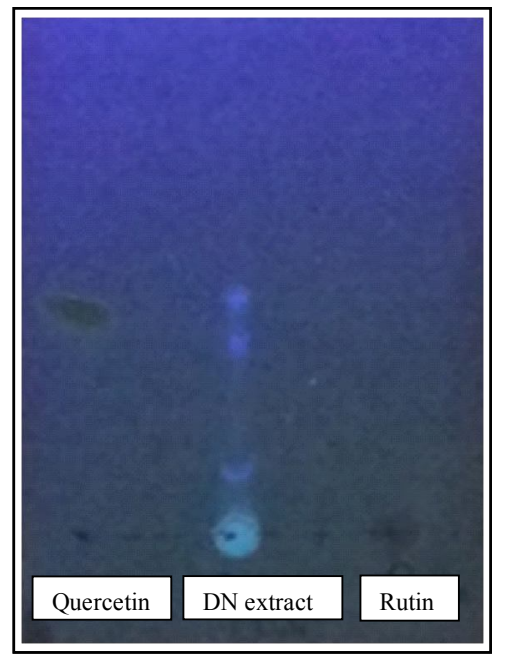

Figure 4(a): TLC of flavonoid, present in DN leaf extract.

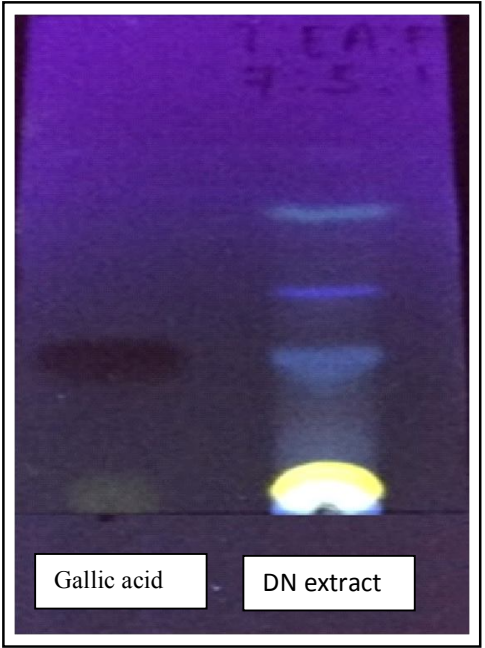

Figure 4(b): TLC of Gallic acid, present in DN leaf extract.

The HPTLC fingerprinting analysis was studied according to the aforesaid procedure and the bands were observed on the HPTLC plates by compared with standard gallic acid and quercetin (Figures 5 and 6, respectively, Plate 1) and quantification was done by calculated the Rf values (Table 5). The results from HPTLC finger print scanned at wavelength $366 \mathrm{~nm}$ for methanolic DN leaf sample (microwave extraction) and observed the presence of gallic acid and quercetin in the extract in high content than other mode of extraction (Figure 7). 


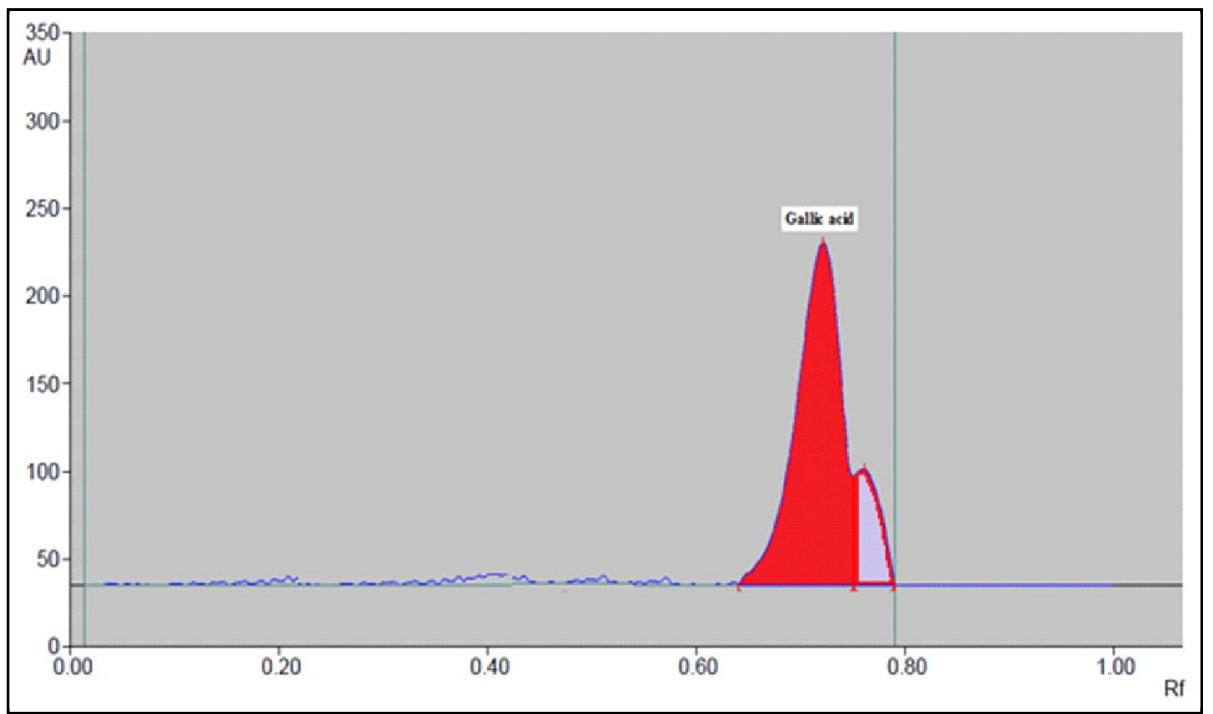

Figure 5: HPTLC chromatogram of standard gallic acid.

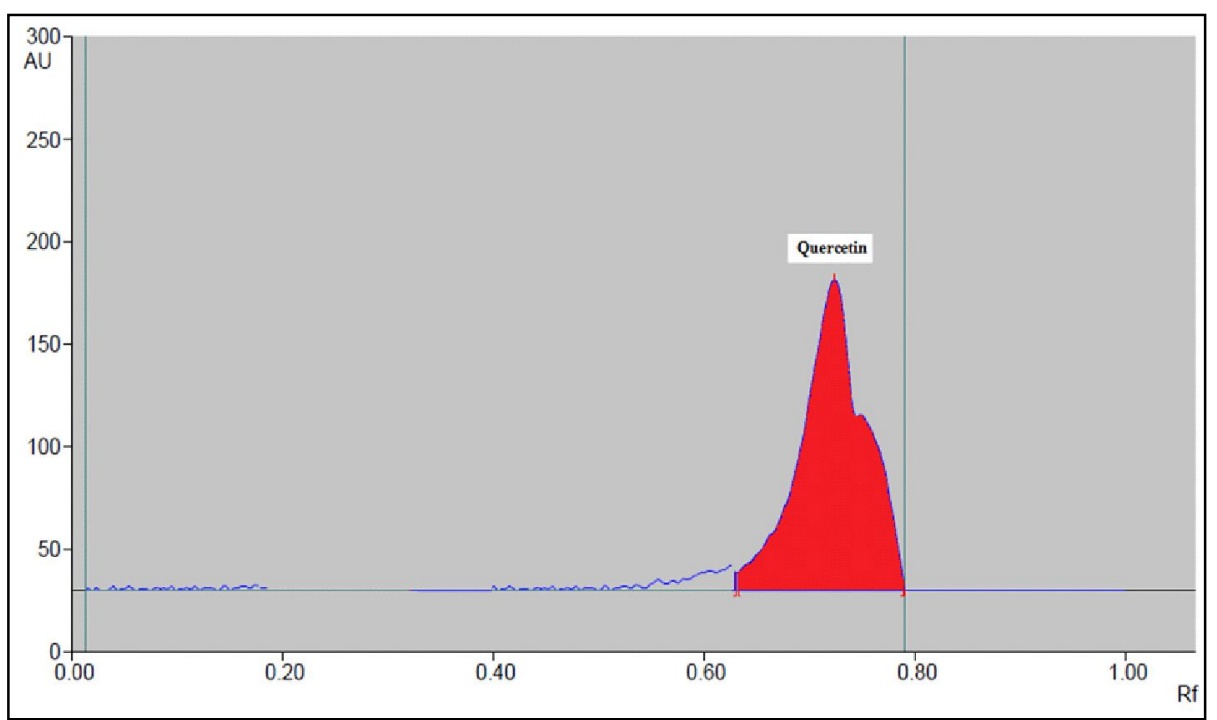

Figure 5: HPTLC chromatogram of standard quercetin.

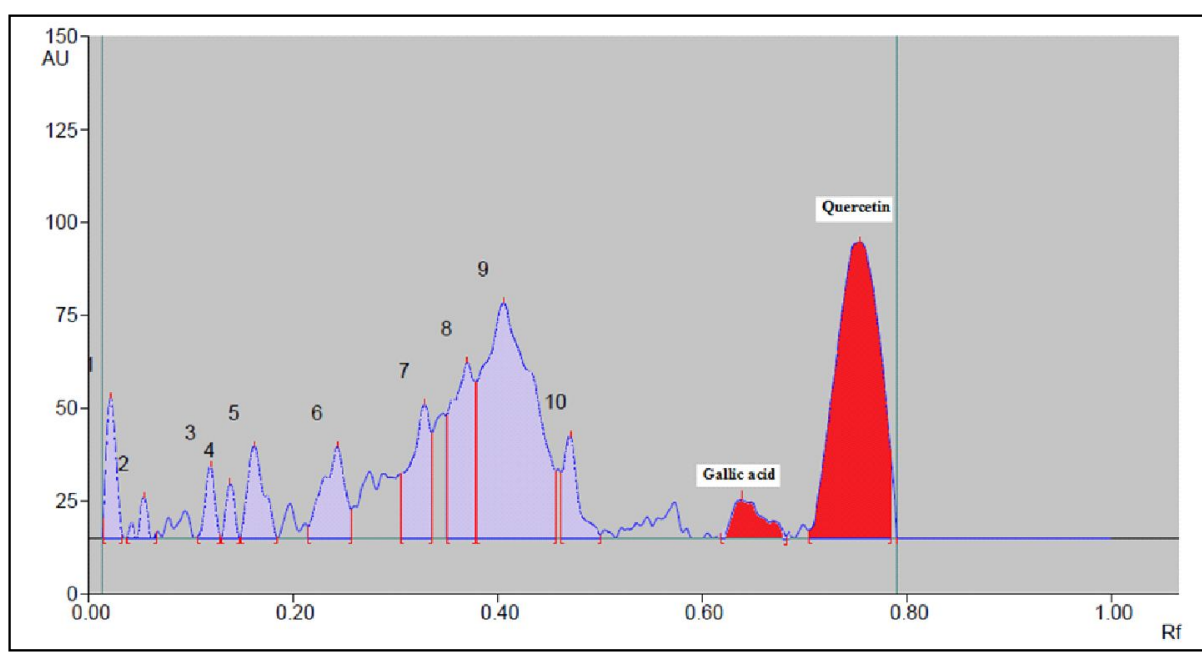

Figure 7: HPTLC chromatogram of gallic acid and quercetin present in DN leaf extract. 


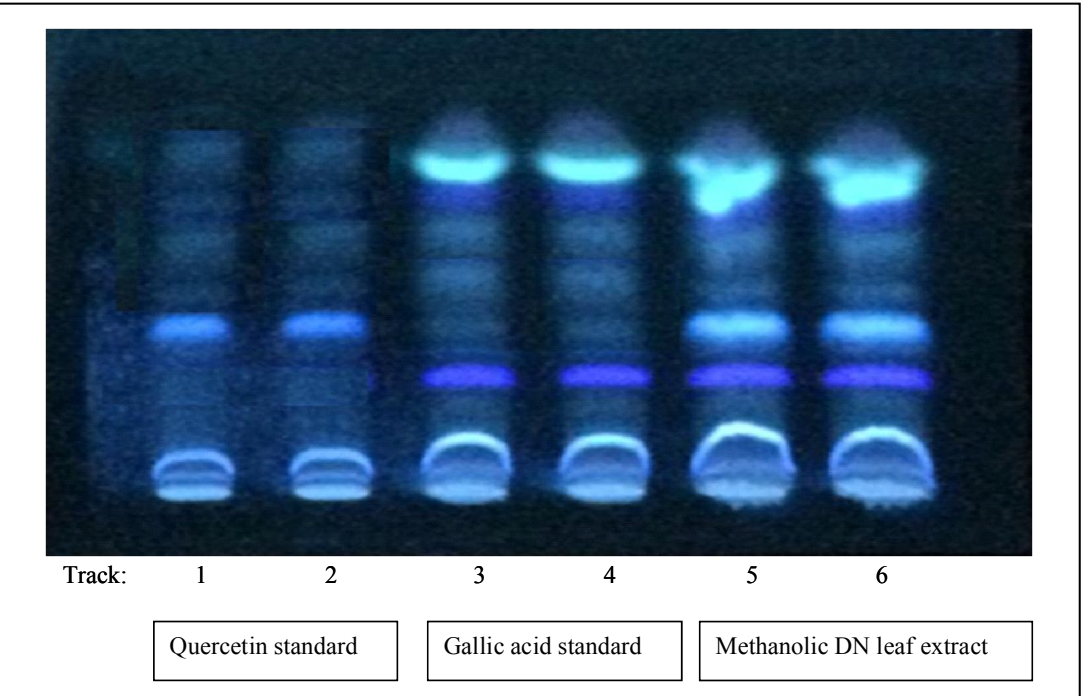

Plate 1: HPTLC for quercetin and gallic acid in methanolic DN leaf extract (at $366 \mathrm{~nm}$ ).

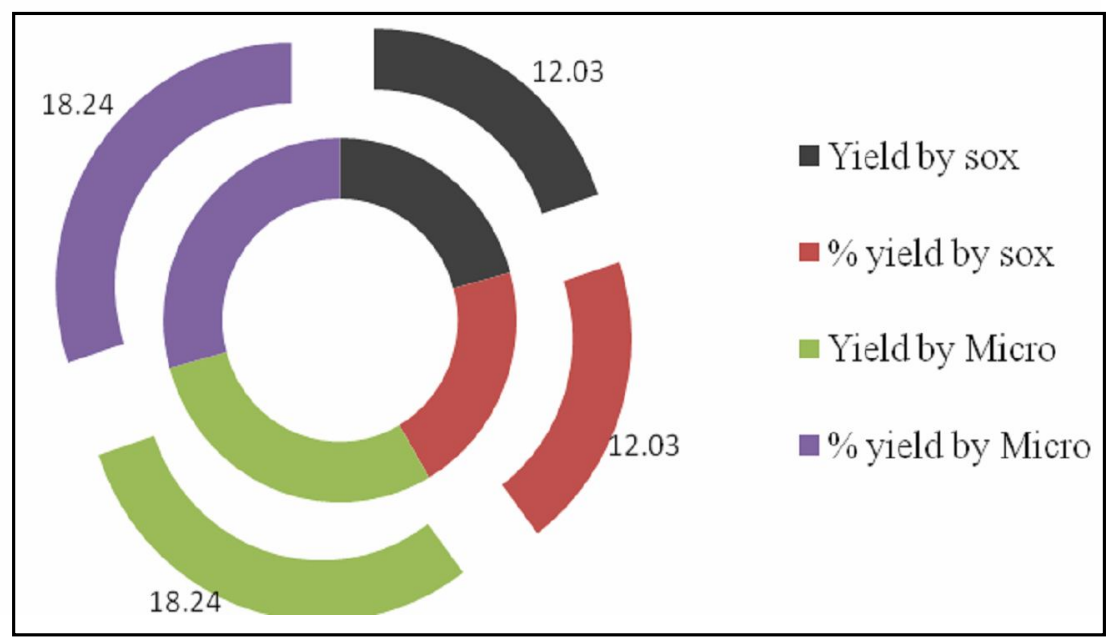

Figure 8: Correlation between yields (g) with percentage yields of various extracts of DN leaf.

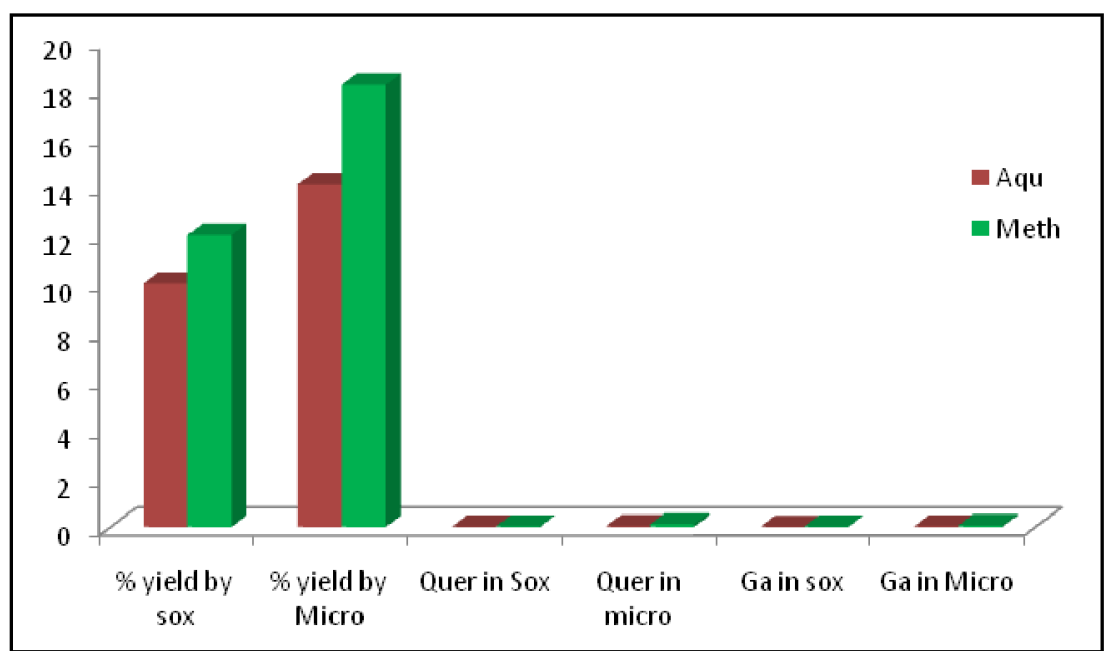

Sox $=$ Soxhlet; Micro $=$ Microwave; Quer $=$ Quercetin; $\mathrm{Ga}=$ Gallic acid; Aqu $=$ Aqueous; Meth $=$ Methano

Figure 9: Correlation among the \% yield and content of phytoconstituents of microwave extracted DN leaf extract. 
Table 5: Quantification of quercetin and gallic acid in DN leaf extracts

\begin{tabular}{|l|c|c|c|c|c|c|c|c|}
\hline \multirow{2}{*}{ Solvents } & \multicolumn{2}{|c|}{ Rf value of quercetin } & \multicolumn{2}{c|}{ Rf value of gallic acid } & Quercetin content(mg/g) & \multicolumn{2}{c|}{ Gallic acid content(mg/g) } \\
\cline { 2 - 10 } & Sox & Micro & Sox & Micro & Sox & Micro & Sox & Micro \\
\hline $80 \%$ methanol & 0.67 & 0.68 & 0.62 & 0.64 & 0.021 & 0.107 & 0.012 & 0.065 \\
Aqueous & 0.66 & 0.67 & 0.62 & 0.63 & 0.013 & 0.028 & 0.008 & 0.024 \\
\hline
\end{tabular}

Sox $=$ Soxhlet method; Micro $=$ Microwave extraction.

\section{Correlation study}

The yield of extract of DN leaf was correlated with various modes of extracted samples such as soxhlet and microwave methods using aqueous and methanol solvents and the result tabulated in Figure 8. Further, \% yield was correlated with the estimated amount of no phytoconstituents present in the various DN leaf extracts. Results showed high significant correlation of the \% yield in microwave extracted sample than others $(p<0.001)$ (Figure 9, Table 6 and 7).

Table 6: Correlation among the \% yield with content of phytoconstituents of microwave extracted DN leaf extract

\begin{tabular}{|l|l|l|l|l|l|l|}
\hline & $\begin{array}{l}\text { \% yield } \\
\text { (Meth) }\end{array}$ & $\begin{array}{l}\text { \% yield } \\
\text { (Aqu) }\end{array}$ & $\begin{array}{l}\text { Quer content } \\
\text { (Meth) }\end{array}$ & $\begin{array}{l}\text { Ga content } \\
\text { (Meth) }\end{array}$ & $\begin{array}{l}\text { Quer content } \\
\text { (Aqu) }\end{array}$ & $\begin{array}{l}\text { Ga content } \\
\text { (Aqu) }\end{array}$ \\
\hline \% yield (Meth) & 1 & & & & & \\
$\%$ yield (Aqu) & 0.786 & 1 & & & & \\
Quer content (Meth) & $0.994 * * *$ & 0.723 & 1 & 1 & & \\
Ga content (Meth) & $0.926^{* *}$ & 0.529 & $0.962 * *$ & 1 & & \\
Quer content (Aqu) & $0.974^{* *}$ & 0.696 & $0.990^{* * *}$ & $0.977 * *$ & 1 & \\
Ga content (Aqu) & 0.292 & 0.700 & 0.184 & -0.090 & 0.085 & 1 \\
\hline
\end{tabular}

Computed " $\mathrm{r}$ " for every pair of data set, confidence interval $>95 \%$. $(* * *)=$ significant at high level $\mathrm{p}<0.001 ;(* *)=$ significant $p<0.01$.

Table 7: Correlation among the \% yield with content of phytoconstituents of soxhlet extracted DN leaf extract

\begin{tabular}{|l|l|l|l|l|l|l|}
\hline & $\begin{array}{l}\text { \% yield } \\
\text { (Meth) }\end{array}$ & $\begin{array}{l}\text { \% yield } \\
\text { (Aqu) }\end{array}$ & $\begin{array}{l}\text { Quer content } \\
\text { (Meth) }\end{array}$ & $\begin{array}{l}\text { Ga content } \\
\text { (Meth) }\end{array}$ & $\begin{array}{l}\text { Quer content } \\
\text { (Aqu) }\end{array}$ & $\begin{array}{l}\text { Ga content } \\
\text { (Aqu) }\end{array}$ \\
\hline \% yield (Meth) & 1 & & & & & \\
\% yield (Aqu) & 0.529 & 1 & & & & \\
Quer content (Meth) & 0.717 & $0.949^{*}$ & 1 & & & \\
Ga content (Meth) & 0.427 & -0.283 & -0.224 & 1 & & \\
Quer content (Aqu) & $0.956^{*}$ & 0.316 & 0.500 & 0.671 & 1 & 1 \\
Ga content (Aqu) & 0.832 & 0.800 & $0.949^{*}$ & -0.141 & 0.632 & \\
\hline
\end{tabular}

Computed "r" for every pair of data set, confidence interval $>95 \%$. $(* * *)=$ significant at high level $p<0.001 ;(* *)=\operatorname{significant} p<0.01 ;(*)=$ significant $p<0.05$.

\section{Discussion}

The proximate analysis in terms of quantitative analysis of various parameters such as total ash, alcohol soluble and acid insoluble ash, moisture content, extractive values are useful for setting standard for the said plant due to limited or no scientific research evidences are established so far. These analyses also help to detect adulteration or identification of authentic species as well as purity of the sample. Generally, morphological identification of powder sample is very difficult until some analysis done for the powder. Based on that, the present investigation was carried out with proximate analysis of the DN leaf sample. The percentage content of the total ash showed higher than other Decalepis species, i.e., D. hamiltonii reported earlier (Das et al., 2017). This increased content of ash may be due to the presence of higher content of plant fibres, inorganic matters that present in the leaf of DN. It was earlier reported that the content of the plant fibres, veins, vein islets is directly proportional to the content of ash, because ash is the inorganic constituents that are present in the leaves which are essential for monograph analysis of any new plants. Hence, the present study showed the same trend as earlier report (Borkataky et al., 2013; Puthalath et al., 2015).

The content of moisture indicates the stability of the phytoconstituents in the plants because more moisture content leads chemical decomposition by the microbial contamination. So, the moisture content as low as preferred to prevents microbial growth and increase the stability of plant constituents (Saleem et al., 2014). Therefore, moisture content for powdered DN leaves was determined and resulted moderate moisture content which is lesser than other Decalepis species (Das et al., 2017). 
Extractive value provides an idea about the solubility nature of the plant constituents that are present in the leaf based plants. Furthermore, extractive value also applied for such materials whose suitable chemical or biological assay does not exists. In the present investigation, extractive value was determined using aqueous and alcohol as solvents for DN leaf powder. The result reported higher percentage of alcohol soluble extractive than water soluble extractive which indicated that maximum phytoconstituents are alcohol soluble due to presence of higher ionic components in the leaf (Chaudhari and Girase, 2015). The results were correlated with the earlier literatures (Vaidya et al., 2017; Sree and Vijayalakshmi, 2018).

Thereafter, many herbals are available whose anatomical nature is unknown. This sometimes affects the purity of drugs as well as greater risk for adulteration or substitution. Hence, powder microscopy helps in monograph analysis and botanical identity of new plant based drugs (Singh et al., 2018). In the present study, the powder microscopy of DN leaf was carried out and finally SEM analysis was performed for confirmation of identified cells and tissue components. The scientific research evidences on powder microscopy as well as SEM analysis on DN leaf sample was still lacking which was fulfilled in this present investigation as the first report.

The percentage yield varied with the solvent and methods used and related many research articles have published (Azwanida, 2015; Dhanani et al., 2017; Gahlot et al., 2018) and the same result revealed in the present investigation. Two different extraction methods, viz., soxhlet and microwave techniques were used for extraction using aqueous and methanol solvents for DN powdered leaf. Results revealed microwave assisted methanol extract gave highest yield than soxhletion method because in microwave method, the microwave radiation interacts with the applied solvents and sample and heat is transferred by conduction (localized temperature and pressure that causes selective migration of targeted compounds from the inside cell to the outside solvent). This resulted disruption of hydrogen bonding that enhanced the migration of dissolved ions and helps solvent to penetrate inside the cell sample that increases highest yield (Kaufmann and Christen, 2002; Dhanani et al., 2017). Hence, among the present extraction methods, microwave extraction was more efficient and effective in terms of less solvent application to procure higher yield. The best yields of particular compounds may also achieve by used several solvents and furthermore degrading enzymes are also denatured or active in either of two extractants. Hence, two different solvents were used in this study. The qualitative determination of plant constituents through various chemical tests is necessary to identify the presence of various groups of phytoconstituents which are ascertaining the therapeutic efficacy. In the present study, two different solvents extracts were tested chemically and revealed the presence of many important active compounds in microwave assisted aqueous extract as well as some are in microwave extracted methanol extract. The variation of results was may be due to the solubility of active components in the specific solvents (Madike et al., 2017). Hence, presence of phenolics, alkaloids, flavonoids were more prominent in microwave extracted methanol sample than aqueous one. Based on the constituents present, further TLC was performed using suitable solvent system (after standardized) and clear separation of gallic acid and quercetin were identified by applied standard drug. Thereafter HPTLC was performed for quantification of these polyphenolic compounds for future isolation of constituents for drug discovery. The method revealed that methanolic extract gave the presence of higher content of phytoconstituents (poly phenolics) than aqueous extract by microwave extraction than soxhlet extraction. The result was also correlated with the earlier literature revealed by Okoduwa et al. (2018).

Finally, correlation was performed between the yields with various phytoconstituents present in both the extracts. Correlation study helps to know about the strong relation associated between different parameters. It was clearly observed that based on method and based on choice of solvent yield also varied and content of phytochemicals also varied. Phytoconstituents are directly proportional to the yield also positively correlated with the solvent use and yield which showed positive correlation which was followed the same trend with the earlier literatures (Das et al., 2017; Irfan and Puratchikody, 2017). These correlations showed the positive mechanism for yields, methods, and solvent used in extraction and their interrelations with content of phytoconstituents present.

\section{Conclusion}

The proximate analysis of DN leaf sample, powder microscopy, SEM analysis, presence of various phytoconstituents, TLC method of separation, their quantification as well as their best way of extraction methods using suitable solvents and the other numerical standards are useful investigation for the compilation of a part of suitable monograph for DN plant. First time, the yield was correlated with quantified plant constituents with positive correlations and also revealed that yield was dependent on type of extractors and type of solvents.

\section{Acknowledgements}

Author is thankful to Rajiv Gandhi University of Health Sciences, Bangalore, India for financial assistance as research grant (Principal Investigator) for carry out the present investigation (Order No: RGU:RGU/ADV.RES/BR/001/2017-18).

\section{Conflict of Interest}

The authors declare that there are no conflicts of interest in the course of conducting the research. Both the authors had final decision regarding the manuscript and decision to submit the findings for publication.

\section{References}

Ajeesh Krishna, T.P.; Adarsh Krishna, T.P.; Kumuthakallavalli, R.; Sanyo Raj, V.N.; Juliet, S.; Shobha Rani, T.; Darsana, U.; Nair, S.N. and Ravindran, R. (2014). Physico-chemical evaluation and biochemical quantification of crude drug powder (stem) of Chassalia curviflora (Wall. ex Kurz.) Thwaites; A folk medicinal plant. J. Pharmacog. Phytochem., 3(4): $121-124$.

AOAC. (1995). Official method of analysis. 16th edition. Association of Official Analytical Chemists, Washington, DC.

Azwanida, N.N. (2015). A review on the extraction methods use in medicinal plants, principle, strength and limitation. Med. Aromat. Plants, 4:196. doi:10.4172/2167-0412.1000196.

Bapat, V.A.; Yadav, S.R. and Dixit, G.B. (2008). Rescue of endangered plants through biotechnological applications. Nat. Aca. Sci. Lett., 31:201210 . 
Borkataky, M.; Kakoty, BB. and Saikia, L.R. (2013). Proximate analysis and antimicrobial activity of Eclipta alba (L.) Hassk: A traditionally used herb. International Journal of Pharmacy and Pharmaceutical Sciences, 5:149-154.

Chaudhari, R.K. and Girase, N.O. (2015). Determination of soluble extractives and physico-chemical studies of bark of Sesbania sesban (L.) Merr. Journal of Chemical and Pharmaceutical Research, 7(8):657-660.

Das, K.; Gowthami, V. and Dang, R. (2017). Comparative proximate analysis, phytochemical screening and antioxidant study of leaf and root extracts of Decalepis hamiltonii Wight \& Arn. Ann. Phytomed., 6(2): 119-125.

Dhanani, T.; Shah, S.; Gajbhiye, N.A. and Kumar, S. (2017). Effect of extraction methods on yield, phytochemical constituents and antioxidant activity of Withania somnifera. Arabian J. of Chem., 10(1):S1193S1199.

Gahlot, M.; Bhatt, P. and Joshi, J. (2018). Study on yield of plant extracts using different solvents and methods. Bull. Env. Pharmacol. Life Sci., 7(6):65-67.

Harborne, J.B. (1973). Phytochemical Methods. Chapman and hall limited, London, pp:49-188.

Hassoon, I.M.; Kassir, S.A. and Altaie, S.M. (2018). Review of plant species identification techniques. International Journal of Science and Research, 7(8):325-328.

Ionta, G.M. (2009). Phylogeny reconstruction of periplocoideae (apocynaceae) based on morphological and molecular characters and a taxonomic revision of Decalepis. The Ph.D. Thesis, University of Florida.

Irfan, N. and Puratchikody, A. (2017). Advancement of tota phytoconstituent extraction process by new way factor analysis for Tridax procumbens L. Int. Res. J. Pharm., 8(10):167-173.

Kaufmann, B. and Christen, P. (2002). Recent extraction techniques for natural products: Microwave assisted extraction and pressurized solvent extraction. Phytochem. Anal., 13:105-113.

Madike, L.N.; Takaidza, S. and Pillay, M. (2017). Preliminary phytochemical screening of crude extracts from the leaves, stems and roots of Tulbaghia violacea. Inter. J. Pharmacog. Phytochem. Res., 9(10): 1300-1308.

Murti, P.B. and Seshadri, T.R. (1941). A study of the chemical components of the roots of Decalepis hamiltonii (Makali veru), Part II-A note on the preparation of inositol by solvent extraction. Proc. Ind. Acad. Sci. A., 13:263-265.
Nagarajan, S.L.; Rao, L.J.M. and Gurudatta, K.N. (2001). Chemical composition of the volatiles of Decalepis hamiltonii Wight \& Arn. Flavour Frag. J., 16:27-29.

Okoduwa, S.I.R.; Okpe, O.; Okoduwa, U.J.; Igiri, B.E.; Mhya, D.H. and Mbora, L.O. (2018). Comparison of yield and phytoconstituents of vernonia amygdalina and Ocimum gratissimum leaves extract from three extraction methods. International Journal of Biomedical and Clinical Sciences, 3(2):27-34.

Phartyal, S.S.; Thapliyal, R.C.; Koedam, N. and Godefroid, S. (2002). Ex situ conservation of rare and valuable forest tree species through seed gene bank. Curr. Sci., 83:1351-1357.

Puthalath, S.; Dang, R. and Das, K. (2015). Total safety management through standardization of formulated ayurvedic kajal using Eclipta alba and Vernonia cinerea herbs. World Scientific News, 5:32-44.

Saleem, U.; Hussain, K.; Ahmad, M.; Bukhari, N.I.; Malik, A. and Ahmad, B. (2014). Physicochemical and phytochemical analysis of Euphorbia helioscopia (L.). Pak. J. Pharm. Sci., 27(3):577-585.

Sharma, S. and Shahzad, A. (2014). An overview on Decalepis: A genus of woody medicinal climbers. J. Plant Sci. Res., 1(1):104.

Singh, D.; Aeri, V. and Ananthanarayana, D.B. (2018). Development of internet technology TIPHAM (Tool for identity of powdered herbals through analytical microscopy) for microscopic identification of crude drugs. Phcog. Mag., S1:213-216.

Sofowara, A.E. (1993). Medicinal plants and traditional medicine in Africa. 2nd edition. Spectrum Books, Ibadan, Nigeria, pp:289.

Sree, T.L. and Vijayalakshmi, K. (2018). Proximate composition, nutritional evaluation and mineral analysis in the leaves of an indigenous medicinal plant, Alternanthera sessilis. Int. J. Health Sci. Res., 8(7):55-62.

Tiwari, S.S.; Srivastava, A.; Srivastava, S. and Rawat, A.K.S. (2012). Isolation and quantification of vanillin through flash and HPTLC chromatographic techniques from Decalepis hamiltonii Wight \& Arn. root and their antioxidant activity. J. Liq. Chro. Reltd. Tech., 35:2396-2407.

Trease, G.E. and Evans, W.C. (1989). Pharmacognosy. 11th edition., Brailliar Tiridel Can. Macmillan Publishers, pp:257.

Udayan, P.S.; Robi, A. J. and Anilkumar, K.A. (2013). Decalepis nervosa (Apocynaceae, Periplocoideae): A rare and little known endemic plant from Kerala. Nelumbo, 55:188-190.

Vaidya, V.V.; Shinde, M.A. and Pradhan, P.M. (2017). Proximate analysis and heavy metal determination of leaf of Capparis spinosa L. International Journal of Research in Pharmacy and Chemistry, $7(4): 382-386$

Zhang, Q.; Zhao, Y.; Wang, B.; Feng, R.; Liu, X. and Chen, T. (2002). New pregnane glycosides from Stelmatocrypton khasianum. Steroids, 67:347-351.

Citation: M. Saifulla Khan and Kuntal Das (2019). Effect of solvents and extractors on proximate analysis, pharmacognostical screening and chromatographic analysis of Decalepis nervosa (Wight \& Arn.) Venter leaf : An endangered plant from Western Ghats region. Ann. Phytomed., 8(2):64-74. 